\title{
ROLES OF HIGHER EDUCATION INSTITUTIONS (HEIS) IN PRODUCING HOLISTIC GRADUATES
}

\author{
Eshaby Mustafa ${ }^{1}$ \\ School of Tourism, Hospitality and Event Management, \\ Universiti Utara Malaysia (UUM), Kedah, Malaysia. \\ (Email: eshaby@uum.edu.my) \\ Nurhazlina Mohd Ariffin ${ }^{2}$ \\ School of Applied Psychology, Social Works and Policy, \\ Universiti Utara Malaysia (UUM), Kedah, Malaysia. \\ (Email: nhazlina@uum.edu.my) \\ 'Ain Husna Mohd Arshad ${ }^{3}$ \\ School of Law, Universiti Utara Malaysia (UUM), Kedah, Malaysia. \\ (Email: ainhusna@uum.edu.my) \\ Ani Munirah Mohamad ${ }^{4}$ \\ School of Law, Universiti Utara Malaysia (UUM), Kedah, Malaysia. \\ (Email: animunirah@uum.edu.my) \\ Nur Aili Hanim Hanafiah ${ }^{5}$ \\ School of Government, Universiti Utara Malaysia (UUM), Kedah, Malaysia. \\ (Email: aili@uum.edu.my)
}

Received date: 04-04-2019

Revised date: 08-04-2019

Accepted date: $29-07-2019$

Published date: 12-09-2019

To cite this document: Mustafa, E., Mohd Ariffin, N., Mohd Arshad, 'A. H., Mohamad, A. M. \& Hanafiah, N. A. H. (2019). Roles of Higher Education Institutions (HEIs) in Producing Holistic Graduates. International Journal of Education, Psychology and Counseling, 4 (32), 29-42.

DOI: $10.35631 / \mathrm{IJEPC} .432004$

Abstract: Higher education institutions (HEIs) largely aim to produce holistic graduates, best in both worlds of academic and non-academic aspects. Although numerous literatures have identified and described "holistic education", it remains an issue if the students actually understand and appreciate the said term. Accordingly, this study seeks to investigate the students' perception of HEI's role of producing holistic graduates. Therefore, this paper seeks to answer two research questions, firstly, what are the characteristics of holistic graduates? And secondly, how do students perceive the academic and non-academic programs at the HEIs towards producing holistic graduates? Engaging in mixed approaches of quantitative and qualitative, this study investigates the students' perception of HEI's role of producing holistic graduates. An online survey was administered on 357 students of a targeted HEI. The findings reveal that majority of the students are satisfied with the academic and non-academic programs offered at the HEI, as well as their perceived concept of the "holistic graduate" itself. Hopefully, the paper would shed light onto further research in the area of students' education and higher learning education generally. 


\section{Introduction}

The basic principles of holistic education are to provide an education that facilitates the students' development, honouring each students' individual needs and abilities, interconnecting experience and reality, autonomy to facilitate appropriate learning, outcomebased education, and students-centered learning (Hare, 2006). Although the working definition of holistic education remains elusive and unclear, several studies attempted to discuss the aspect that encompass this approach. For example, holistic education emphasized on the relationship and interconnectedness between an individual and the community around us (Clark, 1988). Furthermore, individuals have a personal responsibility towards the wellbeing of their community and the holistic educational approach demands us to respect that.

On a different perspective, the holistic approach in education warrants an individual to develop a relationship and transferability between the areas of their knowledge and expertise with the world and others around them (Hare, 2006). In return, the student will appreciate individual differences and ability, which will promote the value of teamwork and group responsibilities in their future undertakings. Understanding the value of holistic approach in education will allow educators to nurture the behaviours that could be manifested through it. Students will also benefit from holistic education where it leads to their personal development and growth through this educational intervention.

It remained a challenge for Malaysia's higher education institution (HEI) to provide a holistic approach in its education to prepare the graduates for employment. In support of this, a notable number of Malaysian employers claimed that many graduates lack the holistic skills and qualifications demanded by the industry (Jusoh et al., 2011). Malaysia, with its rapid economic growth has led to vast development in the areas of socio-economic aspect especially in education. Currently, with as many as 20 public universities and 53 private universities (MOHE, 2019), Malaysia produces more than 180,000 diploma and degree graduates that entered the workforce annually over the period of 2010-2017 (Business Insider, 2018). However, only about 90,000 high-skilled jobs were created over that time. This raised concerns about the rest of the fresh graduates who remained unemployed. It was reported that poor communication and problem-solving skills, lack of industrial training exposure, bad attitude, job-hopping, lack of self-confidence, lack of excellence were the factors that leads to the unemployment problem among the Malaysian graduates (Graduan2U, 2010; Hanapi \& Nordin, 2014). Hence, the Malaysian HEIs has a sufficiently great role in developing holistic education in support of fresh graduates' prepareation for employment.

Although past literature have presented the conceptualisation of "holistic", the true understanding and appreciation of the term on the part of the students is questionable. The problem seems to lie in the students being engaged in both the academic and non-academic programs at the HEIs without actually understanding the true concept of engaging in "holistic" education. The danger of this phenomenon is that the students might not truly appreciate the direction of their output of being "holistic graduates" when they just pick up bits and pieces of the education without having the true understanding of the entire concept of "holistic" itself. Based on this premise, this study aims to investigate the students' perception of the term "holistic" itself, and subsequently, their perception of the HEI's roles of producing holistic graduates. 


\section{Research Objectives}

The objectives of this study are two-folds:

1. To analyse the characteristics of holistic graduates.

2. To investigate the students perception of the academic and non-academic programs at the HEIs towards producing holistic graduates.

\section{Conceptualising Holistic Education}

A number of key terms are engaged in this research, particularly surrounding the concept of holistic education. Among others, the term holistic itself, as well as various academic and non-academic programs at HEIs.

\section{Holistic}

In essence, the HEIs are actually aimed at producing graduates who are balanced in their knowledge and skills, both academic and non-academic. Accordingly, Merriam-Websters Dictionary (1996) defined 'holistic' to be "relating to or concerned with wholes or with complete systems rather than with the analysis of, treatment of, or dissection into parts. Along the same line of thought, Cambridge Dictionary (2008) defined the term as 'dealing with or treating the whole of something or someone and not just a part. Additionally, Gidley (2010) advocates that holistic education balances intellectual/cognitive, artistic/imaginative and practical/life-skills education. Literature seem to indicate that in order to qualify to be termed as "holistic" the education is not only confined to academic classes and lectures, but also extends to non-academic activities. Ultimately, the end result of the education system is to produce graduates who are holistic in academic knowledge and non-academic skills. Simply put, the term 'holistic' means to balance between academic and non-academic knowledge, which could be summarised into the following Table 1.

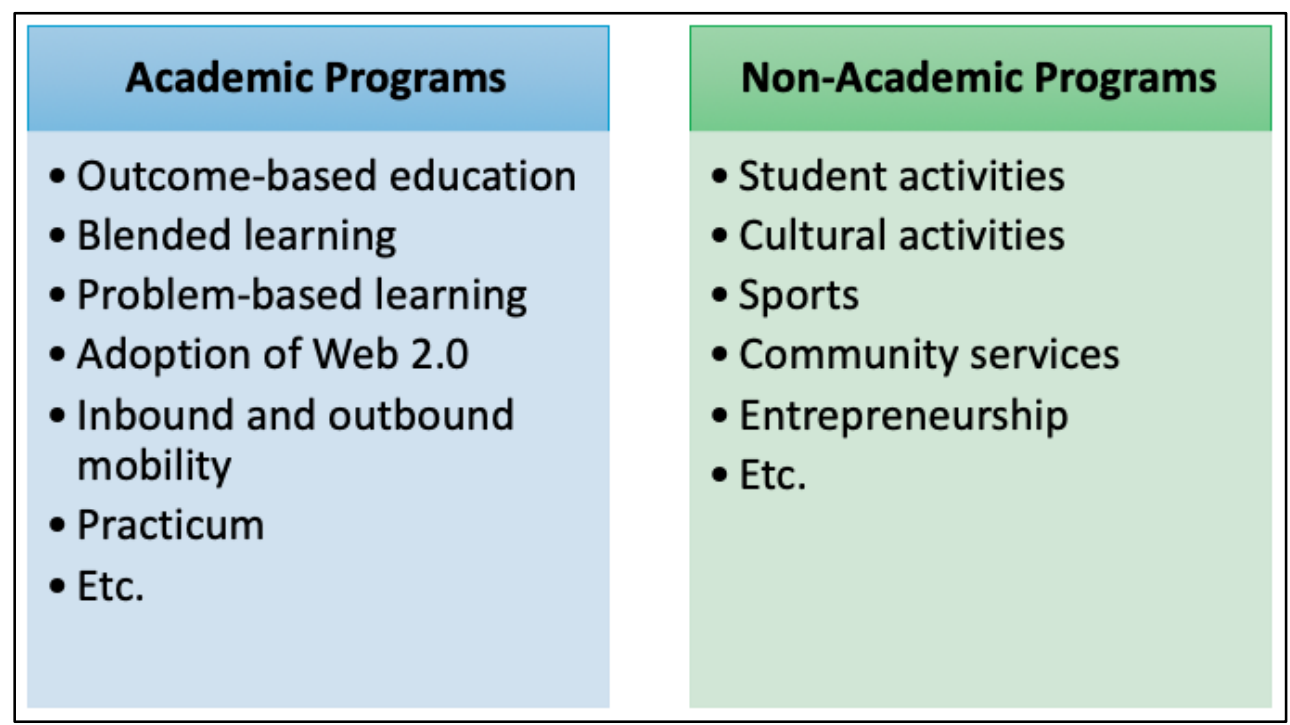

Table 1: Conceptualising "Holistic” Education

\section{Academic Programs}

In this regard, among the academic programs engaged by the students at HEIs are:

- Outcome-based education - it is the type of teaching and learning focusing on the outcome intended by the course. For instance, the course intends for the students to enhance their communication skills, then the learning activities would involve various tasks aimed at enhancing the communication skills of the students (Midraj, 2018). In essence, this approach entails that by the end of the lesson, the students would have 
achieved the intended learning outcome for the specified lesson, for instance being able to apply, practise or explain certain aspects of the lesson.

- Blended learning - it is the type of teaching and learning combining both online learning as well as face-to-face learning. Past literature have shown enhanced performance of the students upon engaging in the blended learning method (Jani, et. al, 2018). Ultimately, the students would be engaging in both online learning as well as face-to-face methods in appreciating and learning the lessons planned by the teachers.

- Problem-based learning - when students engage in problem-based learning, their learning activities would comprise of mostly of issues, problems and situations to enhance the students' problem solving skills (Savery \& Duffy, 1995). Accordingly, students engaging in this approach of learning would be tasked with hypothetical problems and situations revolving around the specific lessons, for which they would propose solutions or methods of resolving such disputes. Hopefully, when they face such problems in the real world situation, they would be able to handle such issues handsomely.

- Adoption of Web 2.0 - teaching and learning also is moving towards increased engagement of WEB 2.0 tools, such as online gamification, Padlet, multimedia learning as well as online assessment tools. There are tonnes of web tools out there, some are freeware while some are shareware, to be used by both the students and the teachers.

- Mobility - it is the learning type which allows for students exchange between one HEI to another HEI. This would include both inbound mobility (where students from other HEI come to that respective HEI) an outbound mobility (where students from that respective HEI go to another HEI). Past literature have reported increased exposure and learning experiences gathered by students involved in mobility programs (Verbik \& Lasanowski, 2007).

- Practicum - practicum or industrial training is the attachment program imposed on the students of HEIs, often as part of the curriculum requirements of the academic program, combining both technical skills as well as soft skills. Through this method of learning, students would be attached with industrial offices and engage in hands-on learning with actual cases under the guidance of the industrial managers (Lockwood-Rayermann, 2003).

\section{Non-Academic Programs}

On the other hand, among the non-academic programs engaged by the students at HEIs are:

- Student activities - students involve in various activities, such as industrial talks, career advisory workshops, games and various other activities - all aim towards enhancing the teamwork, project management and communication skills of the students at HEIs.

- Cultural activities - other than that, students also engage in various cultural activities at HEIs such as theatre plays, cultural performances, all aimed at enhancing the creativity of the students.

- Sports - sports activity are also engaged by the students, such as horse-riding, go-karting, canoeing, cycling, swimming and various other sports activities. All these are aimed at enhancing the students' teamwork and communication skills.

- Community services - it is the type of activities which involve any chosen community for the purpose of giving back to the community, such as visit to old-folks homes, clean and improve the beach area, and other sort of community services.

- Entrepreneurship - and the last but not least, the students also engage in entrepreneurship activities, such as participating in car-boot sales, food kiosks, and other activities, particularly aimed at enhancing the entrepreneurship skills of the students. 
Combining both the learning approaches of academic and non-academic, students of HEIs are expected to enhance their potential of becoming holistic graduates, in line with the HEI's role of producing holistic graduates and holistic leaders.

\section{HEI's Role in Producing Holistic Graduates}

It is evidence that individuals' access and opportunities to learn and develop throughout their life can bring prosper to both social and economic terms of communities around the world. The current labour market demands graduates of HEI to be equipped with the ability to interact in a global setting, and possess various skills. However, the educational concepts and approaches being practiced in HEIs are still too narrow (Saulich \& Lehmann, 2017). Therefore, strengthening HEI's mission to produce holistic graduates is now a focus. HEI must engage with community needs and market demands by integrating the university's activity with socio-economic context (Ehlers, 2017).

The call for transformative changes to holistic approach in HEI has been the highlight in sustainable education for many years. It was argued that there is not enough institutional support and incentives for those academics willing to integrate more holistic activities in class (Hoover and Harder, 2014), only overcommitted academics are applying the approach (Krizek et al., 2012) and the changes have been little and occurring at a slow pace (Watson et al., 2013).

This study will explore how students' perceived HEI's holistic curriculum assessment, in order to provide an overview of the contribution of the courses and the degrees they are taking. This will later help the university to foster educational changes and guiding them to revise the curriculum in their effort to promote holistic learning.

\section{Methodology}

The methodology employed in this study is mixed between qualitative and quantitative. The instrument engaged was online survey using Google Forms and administered on 367 students of a chosen HEI, which is a public higher learning institution located at the northern region of Malaysia. A screenshot of the online survey form is produced in Figure 1 below. 


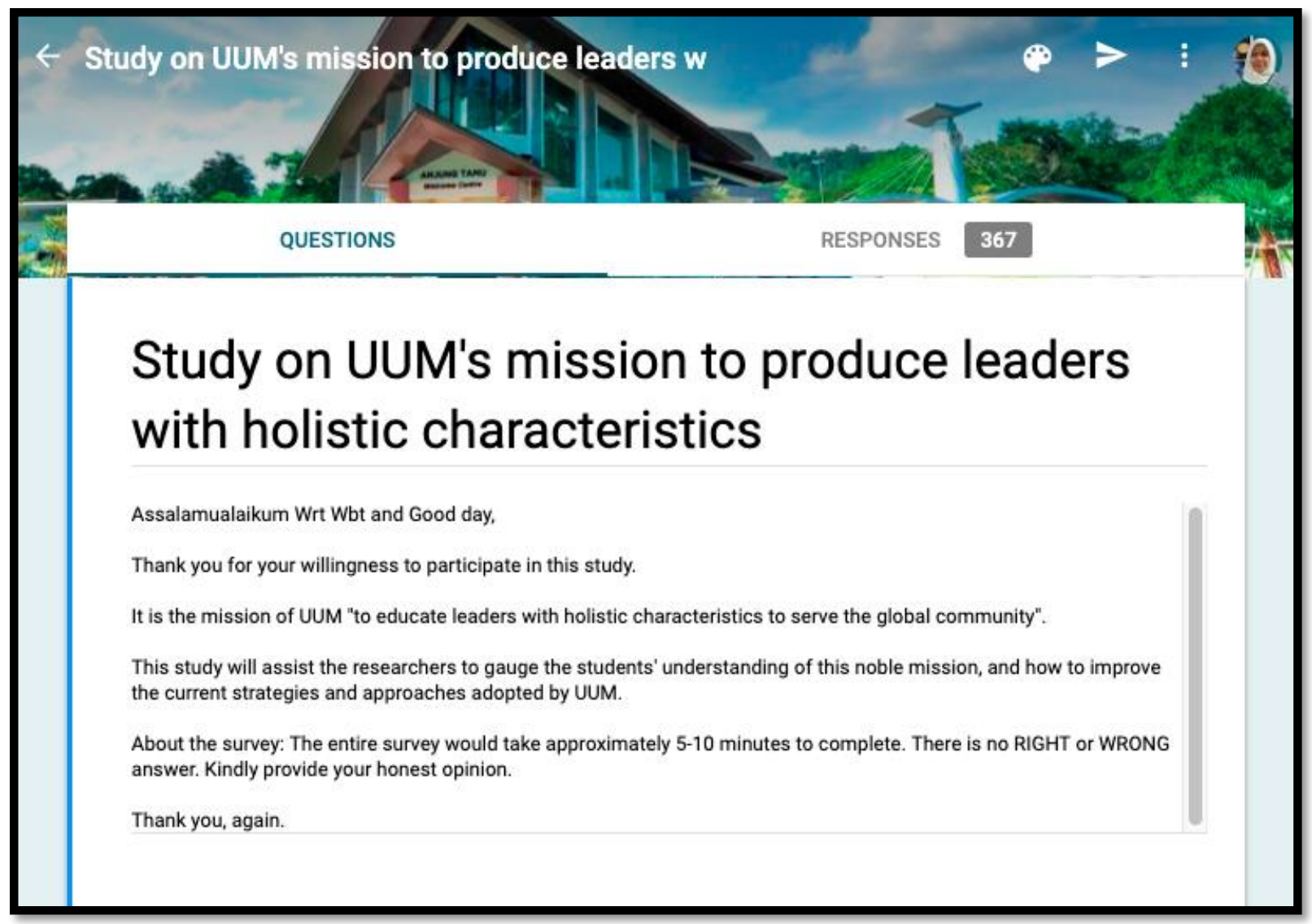

Figure 1: Screenshot of The Online Survey Form

The breakdown of the study programs of the respondents are as produced in Figure 2 below, with 199 respondents $(52.4 \%)$ from legal studies, 99 respondents (27\%) from arts and sciences studies, and 69 respondents (18.8\%) from business studies.

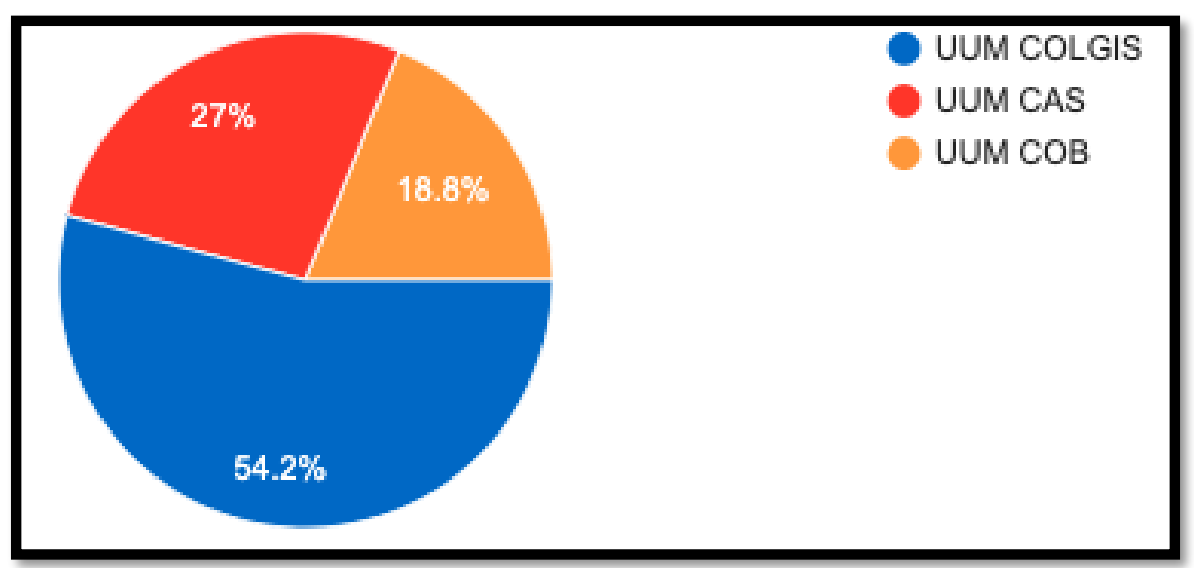

Figure 2: Breakdown of The Respondents by Study Program

The first part of the survey explored the conceptualisation of the term 'holistic' on the part of the survey respondents, while the second part explored the students' perception of various items of both academic and non-academic nature, such as entrepreneurship programs and communication enhancement. 
The data was gathered, scrutinised and analysed using qualitative and quantitative methods. For the qualitative analysis, the responses of the open-ended question on the understanding of the students on the characteristics of holistic graduates were added to the computer-aided qualitative data analysis software ATLAS.ti version 8.4 for the purpose of analysis. The responses were analysed purely inductively to bring out the actual meanings of the terminologies mentioned by the respondents in their survey responses, rather than prescribing the priori codes upfront. The interface of the ATLAS.ti software for this particular analysis is produced in Figure 3 below.

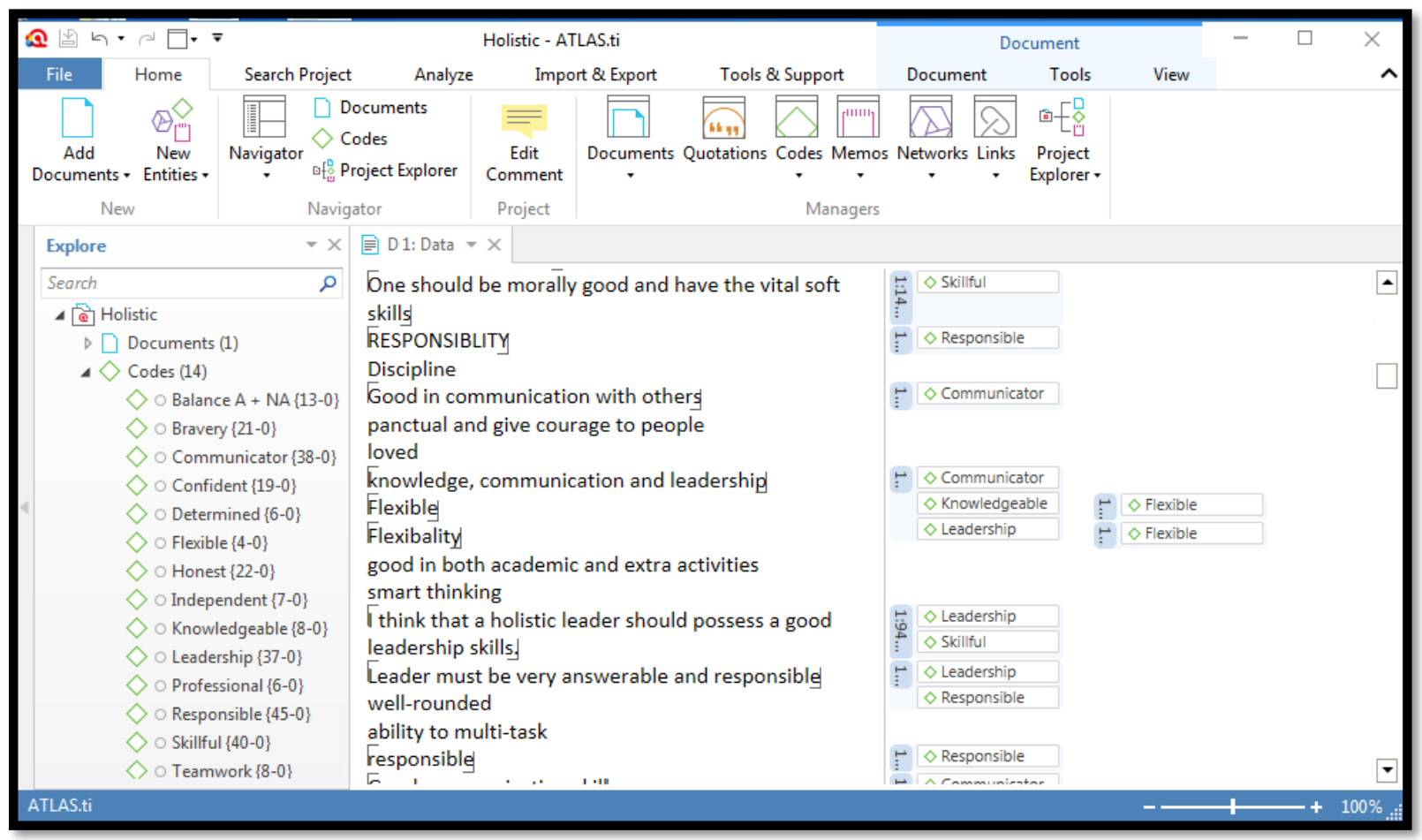

Figure 3: Interface of the ATLAS.ti Software

Meanwhile, for the quantitative analysis, the breakdown of the findings is produced in graphical forms for the purpose of elaborating the preference of the respondents. The findings for both the qualitative and quantitative questions are produced in the following section of "Findings \& Discussion".

\section{Findings and Discussion}

Based on a survey result collected from 367 UUM students who have voluntarily participated in the survey, the following findings were gathered:

\section{Characteristics of Holistic Graduates}

The survey posted an open-ended question for the first research objective of: To analyse the characteristics of holistic graduates. The following word cloud produced in Figure 4 below was generated to capture the key terms of the characteristics of 'holistic' graduates as perceived by the students. Among the glaring literal terms found to be the characteristics of holistic graduates are: communication (27 times), bravery (20 times), leadership (25 times), responsibility (35 times), confidence (17 times) and skilful (25 times). 


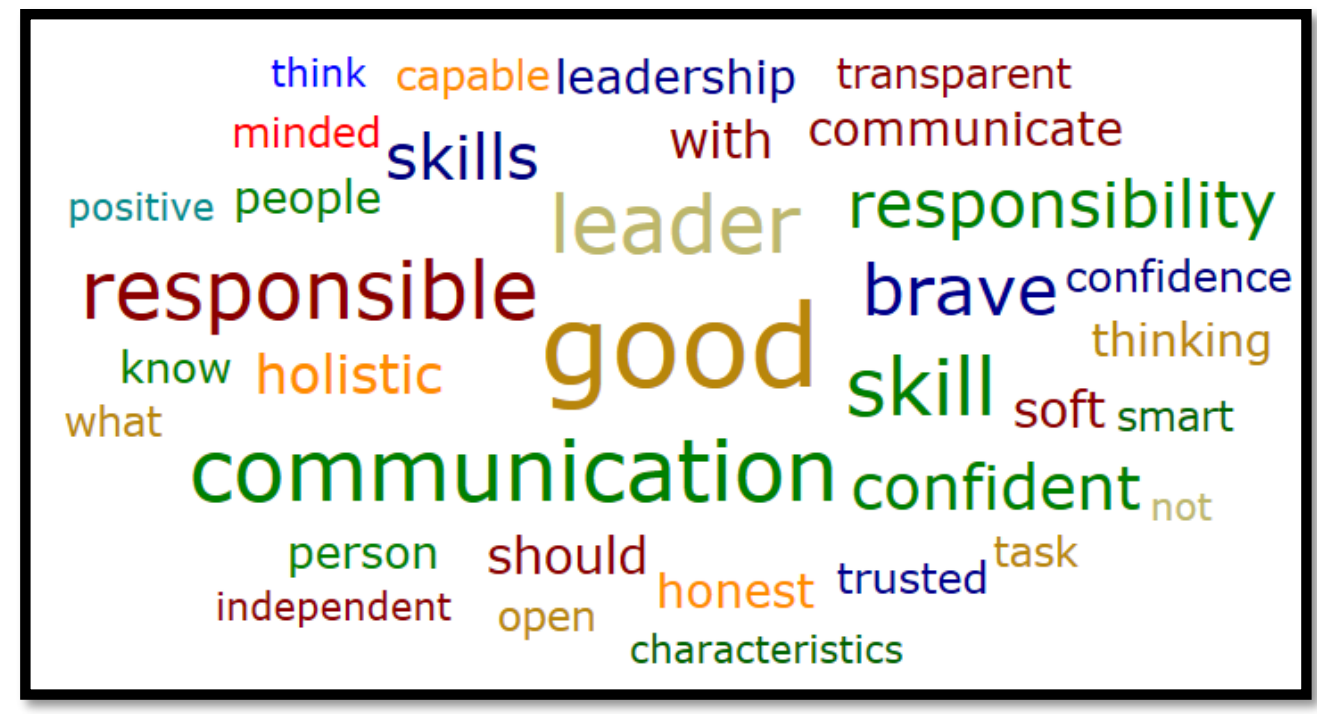

Figure 4: Characteristics of Holistic Graduates

Digging deeper into the perception of the respondents on the characteristics of holistic graduates, the following inductive codes were developed from the survey responses, and the top 10 codes are produced in the following Table 1.

\begin{tabular}{|c|l|c|}
\hline & \multicolumn{1}{|c|}{ Codes } & Frequency \\
\hline 1 & Responsible & 45 \\
\hline 2 & Skillful & 40 \\
\hline 3 & Communicator & 38 \\
\hline 4 & Leadership & 37 \\
\hline 5 & Honest & 22 \\
\hline 6 & Bravery & 21 \\
\hline 7 & Confident & 19 \\
\hline 8 & Knowledgeable & 8 \\
\hline 9 & Teamwork & 8 \\
\hline 10 & Independent & 7 \\
\hline
\end{tabular}

Table 1: Codes Developed Against the Survey Responses and Their Respective Frequencies

This finding just supported the author's initial proposition that "holistic" means not only the academic achievements of a student, evidenced by only 8 frequency of the statements being coded with 'Knowledgeable', as opposed to the other items on the codes list, which represent the non-academic achievements, or soft-skills which characterise the "holistic graduate". Among others, the non-academic achievements perceived by the respondents to be possessed by a holistic graduate include 'responsible' (45 times), 'skilful' (40 times), 'communicator' (38), 'leadership' (37) and others as can be seen in Table 1 above.

In terms of the balancing between academic and non-academic activities of the "holistic graduates", the following network from ATLAS.ti is produced as Figure 5 representing the visualisation of the survey responses which support the proposition that "holistic" means balancing between academic and non-academic programs at the university. Shown in the Figure is the actual wordings of the respondents in this regard. 


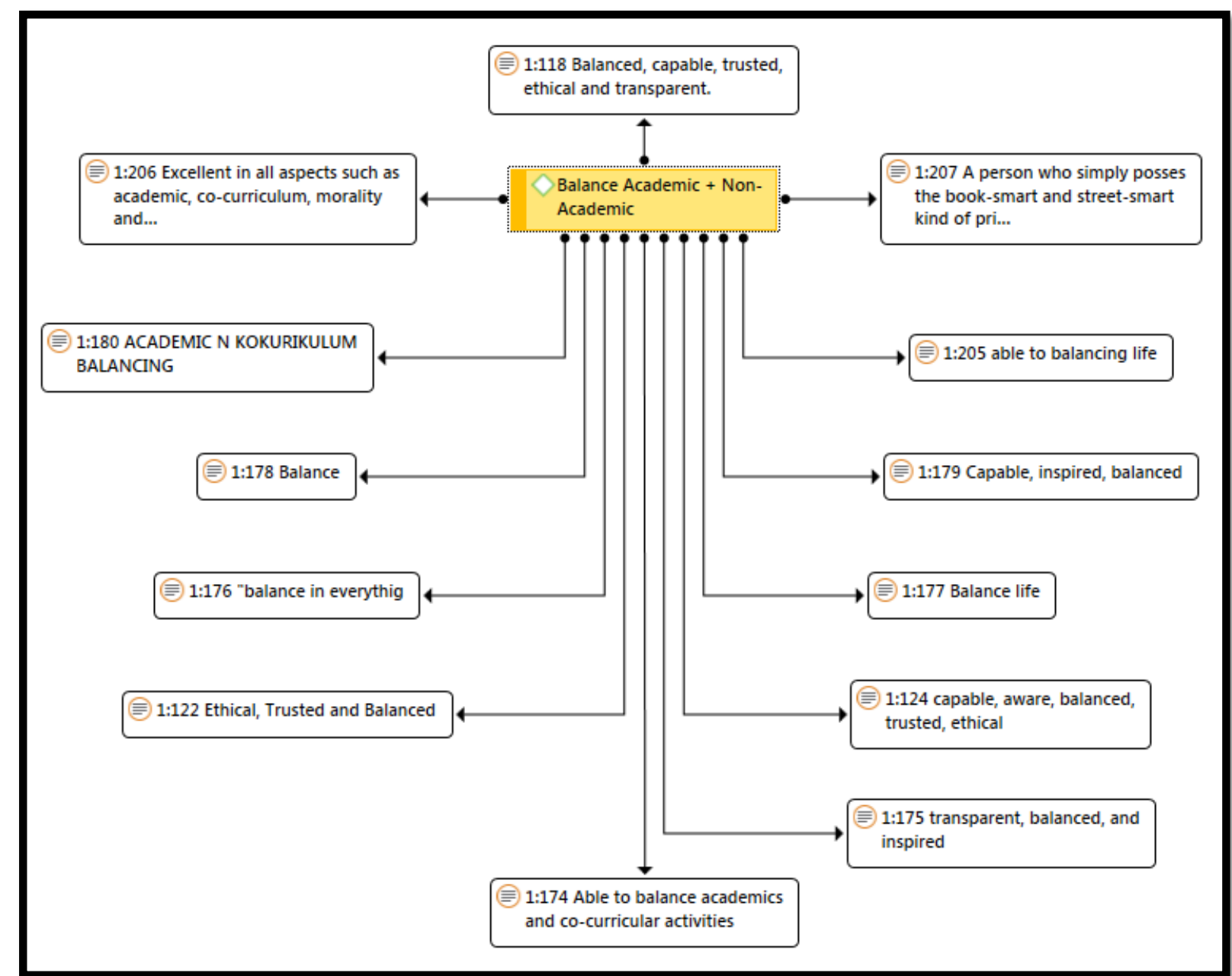

Figure 5: Survey Responses on Balancing of Academic and Non-Academic Activities of "Holistic Graduates"

\section{Students' Perception of HEI's Role Of Producing Holistic Graduates}

For the second research objective of: To investigate the students' perception of the academic and non-academic programs at the HEIs towards producing holistic graduates, eight statements were presented to the respondents, upon which the survey provided a five-Likert scale option of:

- Agree very much

- Agree

- Neutral

- Disagree

- Disagree very much 
The findings from the survey is presented in the following Figures 6 and 7.

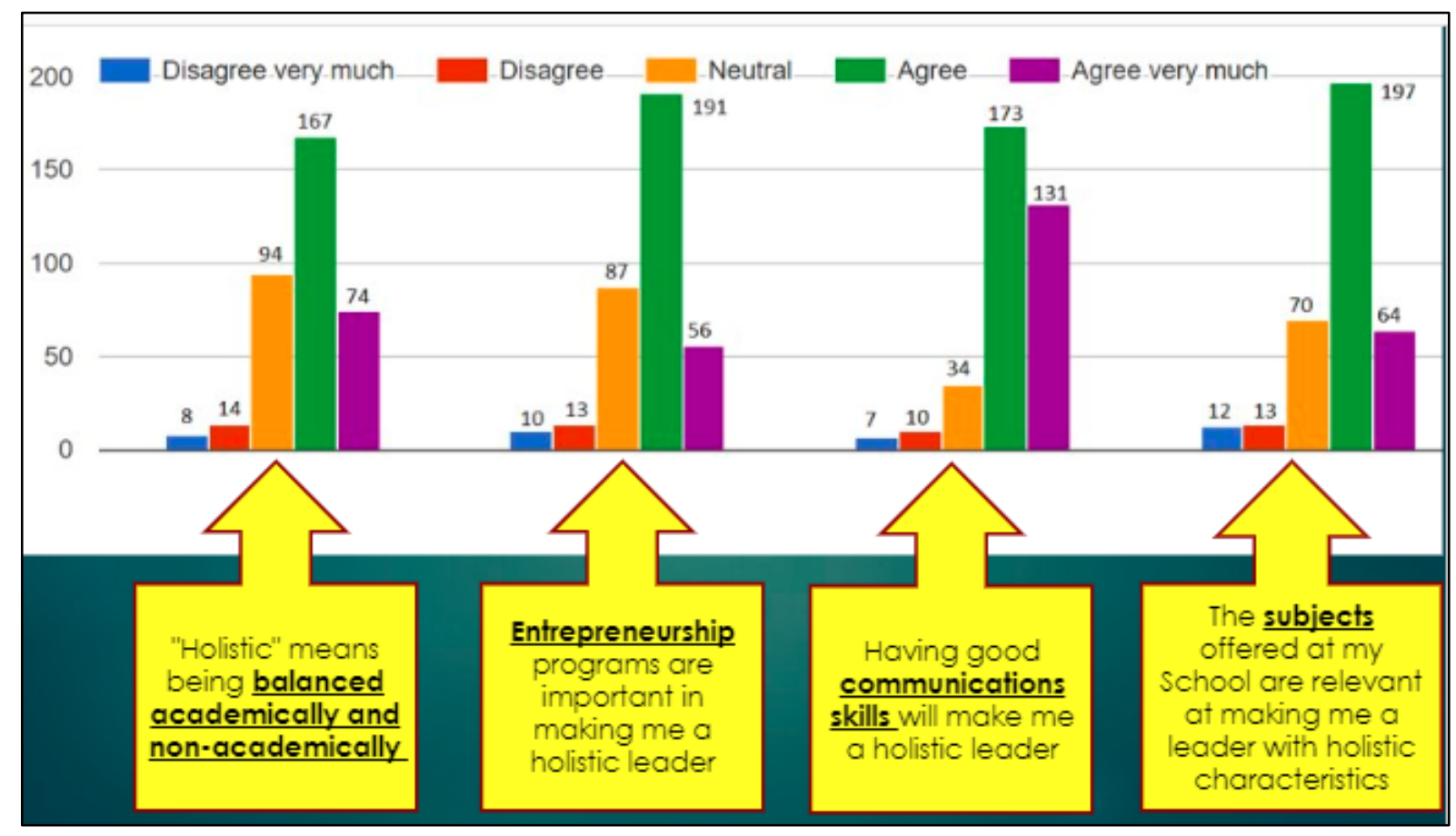

Figure 6: Students' Perception of HEI's Role of Producing Holistic Graduates (Part 1)

With regards to the second research question: How do students perceive the academic and non-academic programs at the HEIs towards producing holistic graduates? The following findings were found:

On the first statement of: "Holistic" means being balanced academically and nonacademically, 241 respondents agree that 'holistic' means balanced academically and nonacademically. Only 22 respondents do not agree with such proposition. Whereas 94 respondents give neutral opinion, probably because they do not have any information about the concept of holistic students.

On the second statement of: Entrepreneurship programs are important in making me a holistic leader, a total of 247 respondents agree with the second proposition that entrepreneurship programs are important in making a student a holistic leader. Whereas, 23 respondents do not agree, and 87 respondents give neutral opinion.

On the third statement of: Having good communication skills will make a holistic leader, 304 respondents agree that good communication skills will make a student a holistic leader. 17 respondents do not agree with this, whereas 34 respondents are neutral.

On the fourth statement of: The subjects offered at my school/faculty are relevant at making me a leader with holistic characteristics, 261 respondents agree that the subjects offered at UUM schools are relevant in making a student a leader with holistic criteria. 25 respondents were not agree with this proposition and 70 respondents are neutral. 


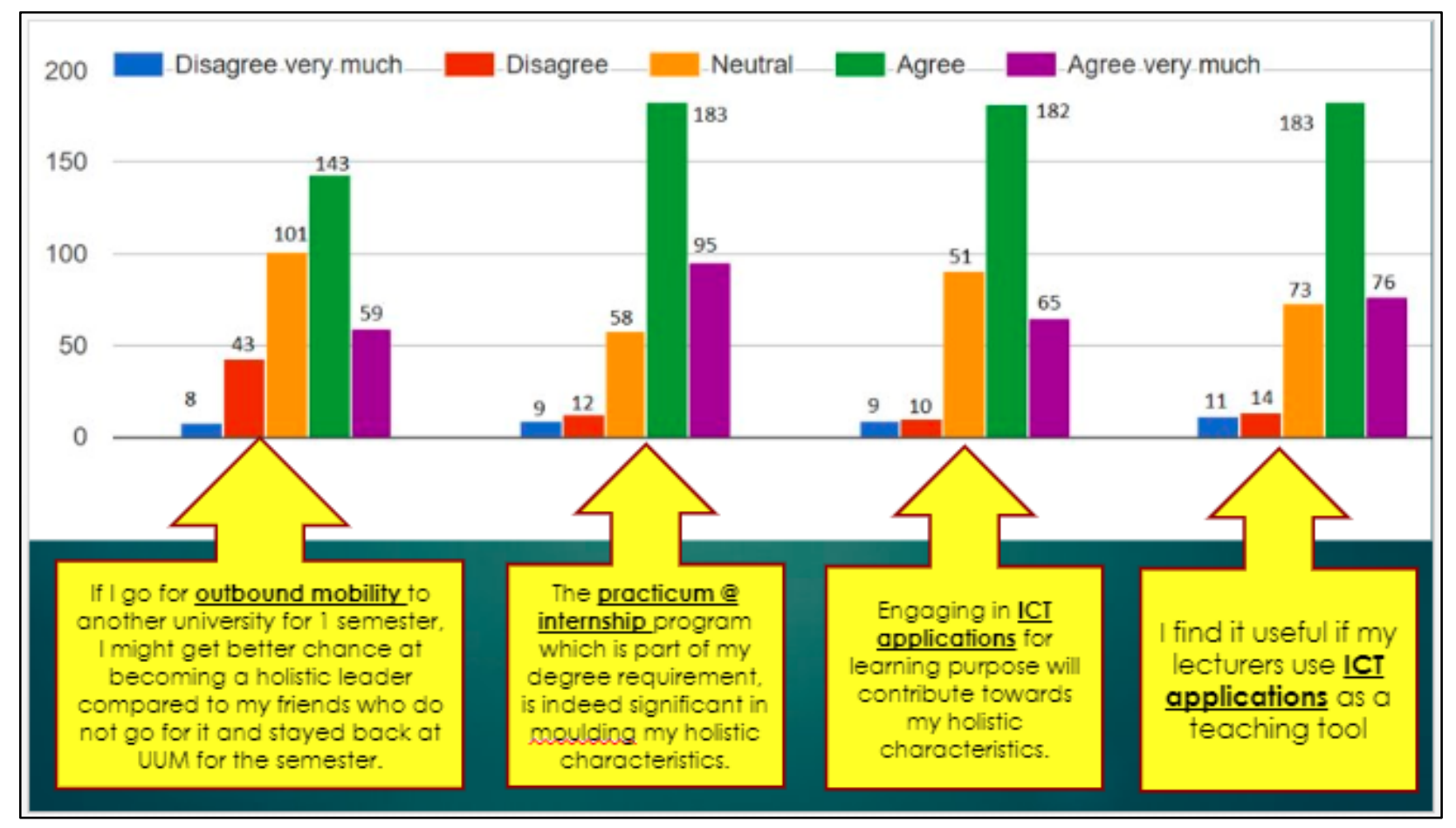

\section{Figure 7: Students' Perception of HEI's Role of Producing Holistic Graduates (Part 2)}

The above figure consists of another four statements, statements fifth to eighth, which indicate students' perception on the academic and non-academic programs at the HEIs towards producing holistic graduates.

On the fifth statement of: If I go for outbound mobility to another university for 1 semester, I might get better chance at becoming a holistic leader compared to my friends who do not go for it and stayed back at UUM for the semester, 202 respondents agree with the statement, while 51 respondents do not agree. 101 respondents give neutral opinion about this statement, which is quite a high number. Perhaps more information on outbound mobility should be disseminated amongst students.

On the sixth statement: The practicum or internship program, which is part of my degree requirement, is indeed significant in moulding my holistic characteristics, 278 respondents agree with this statement. Only 21 respondents do not agree, while another 58 respondents give neutral view. Majority of the respondents agree with this statement, most probably because they have underwent their practicum and feel the impact of practicum in their learning process.

On the seventh statement: Engaging in ICT applications for learning purpose will contribute towards my holistic characteristics, 247 respondents agree with this proposition. 51 respondents give neutral opinion, whereas only 19 respondents disagree. This is a clear indication that the adoption of ICT in classroom is necessary. This is further supported by the final proposition, which is, I find it useful if my lecturers use ICT applications as a teaching tool. 259 respondents agree, only 25 respondents disagree, whereas another 73 respondents give neutral opinion. 


\section{Conclusion}

The study sought to achieve the following two objectives: First, what are the characteristics of holistic graduates? And second, how do students perceive the academic and non-academic programs at the HEIs towards producing holistic graduates? The findings reveal that majority of the students are satisfied with the academic and non-academic programs offered at the HEI, as well as their perceived concept of the "holistic graduate" itself. In essence, for the first research objective, the concept of "holistic" was found to be mostly characterised by: communication, bravery, leadership, honesty, determination and knowledge. For the second objective, majority of the respondents perceived that being "holistic" means being balanced academically and non-academically. Accordingly, both research objectives are achieved in this study. Hopefully, the paper would shed light onto further research in the area of students' holistic education and the demand of holistic graduates in the current labor market.

Following the findings of the study, there seem to be a number of challenges that the higher education institutions will have to face in realizing its mission to produce holistic graduates. One of the crucial challenges is concerning attitude and ethical values. There is so much concentration given on knowledge and skills, which are undoubtedly important. However, the focus on these two components should not override values. Concerns in this matter have been mentioned by Swenson and Duin (2018) and Gachago and Sykes (2017) when discussing ethical issues in adopting digital technologies, while Sobaih, Moustafa, Ghandforoush and Khan (2016) discuss the value and use of social media as learning tools. In relation to this, the work authored by Hyland (2017) is useful to study the concept of 'mindfulness' as an ethical foundation to be instilled in students of higher education institutions.

Other challenges that can be identified throughout this study are:

- Staying abreast of new developments in technology and education and understanding their implications

- To get lecturers who are experienced in teaching, research and industrial practice

- To obtain funding for research, seminars and intellectual discourse

- Lack of development support

- Mismatch between the university's curriculum and industry's expectation

- Graduates lack of critical thinking skills and communication skills

- Lack of proper lifelong learning policies, poor awareness and participation in lifelong learning

For future research, it is suggested that studies be conducted to address the above challenges and formulate effective mechanisms in producing holistic graduates that are able to bring positive changes in the society.

\section{References}

Business Insider. (2018). Fresh Graduates in Malaysia Struggling to Find Jobs. Retrieved from: https://www.businessinsider.my/fresh-graduates-in-malaysia-struggling-to-findjobs/

Cambridge Advanced Learner's Dictionary. Recuperado de: https://dictionary.cambridge.org/es/diccionario/ingles/blended-learning.

Clark, E. T. (1988). The search for a new educational paradigm: The implications of new assumptions about thinking and learning. USA Holistic Education Review, Spring.

Ehlers, U. D. (2017). Lifelong Learning: Holistic and Global Education. In 6th ASEF Rectors' Conference \& Students' Forum (ARC6. 
Gachago, D., \& Sykes, P. (2017). Navigating ethical boundaries when adopting digital storytelling in higher education. In Digital storytelling in higher education (pp. 91106). Palgrave Macmillan, Cham.

Gidley, J. (2010). Holistic education and visions of rehumanized futures. RoSE-Research on Steiner Education, 1(2).

Graduan2U (2010), "Five reasons why graduates are unemployed". Retrieved from ; www. graduan2u.com/2010/02/28/five-reasons-why-graduates-are-unemployed

Hanapi, Z. \& Nordin, M.S. (2014). Unemployment among Malaysia graduates: Graduates' attributes, lecturers' competency and quality of education. Procedia-Social and Behavioral Sciences, 1056- 1063.

Hare, J. (2006). Towards an understanding of holistic education in the middle years of education. Journal of Research in International Education, 5(3), 301-322.

Holistic. (1996). Merriam-Webster's Dictionary (10th ed.). Springfield, MA: MerriamWebster Incorporated.

Holistic. (2008). In OxfordDictionaries.com. $\quad$ Retrieved from http://www.oxforddictionaries.com/definition/english/holistic

Hoover, E., \& Harder, M. K. (2015). What lies beneath the surface? The hidden complexities of organizational change for sustainability in higher education. Journal of Cleaner Production, 106, 175-188.

Hyland, T. (2017). Mindful working and skilful means: enhancing the affective elements of vocational education and training through the ethical foundations of mindfulness. In Competence-based Vocational and Professional Education (pp. 145-164). Springer, Cham.

Jani, J., Muszali, R., Nathan, S., \& Abdullah, M. S. (2018). Blended learning approach using Frog VLE platform towards students' achievement in teaching games for understanding. J. Fundam. Appl. Sci, 10, 1130-1141.

Jusoh, M., Simun, M., \& Choy Chong, S. (2011). Expectation gaps, job satisfaction, and organizational commitment of fresh graduates: Roles of graduates, higher learning institutions and employers. Education \& Training, 53(6), 515-530.

Krizek, K. J., Newport, D., White, J., \& Townsend, A. R. (2012). Higher education's sustainability imperative: how to practically respond? International Journal of Sustainability in Higher Education, 13(1), 19-33.

Lockwood-Rayermann, S. (2003). Preceptors, leadership style, and the student practicum experience. Nurse Educator, 28(6), 247-249.

Midraj, S. (2018). Outcome-Based Education (OBE). The TESOL Encyclopedia of English Language Teaching, 1-7.

MOHE. (2019) Ministry of Higher Education, Malaysia. Retrieved from; http://jpt.mohe.gov.my/portal/

Saulich, C., \& Lehmann, T. (2017, June). Boosting the Employability of Students and Staff at European Higher Education Institutions: An Educational Framework for Entrepreneurship, Internationalisation and Innovation. In Proceedings of the 3rd International Conference on Higher Education Advances (pp. 899-907).

Savery, J. R., \& Duffy, T. M. (1995). Problem based learning: An instructional model and its constructivist framework. Educational technology, 35(5), 31-38.

Sobaih, A. E. E., Moustafa, M. A., Ghandforoush, P., \& Khan, M. (2016). To use or not to use? Social media in higher education in developing countries. Computers in Human Behavior, 58, 296-305.

Swenson, J., \& Duin, A. H. (2018). Understanding Ethical Concerns Surrounding Big Data and Learning Analytics in Higher Education. The Wiley Handbook of Educational Policy, 479-511. 
Verbik, L., \& Lasanowski, V. (2007). International student mobility: Patterns and trends. World Education News and Reviews, 20(10), 1-16.

Watson, M. K., Lozano, R., Noyes, C., \& Rodgers, M. (2013). Assessing curricula contribution to sustainability more holistically: Experiences from the integration of curricula assessment and students' perceptions at the Georgia Institute of Technology. Journal of Cleaner Production, 61, 106-116. 